\title{
Study on Practical Experiences of Rural Land Management Right Mortgage Loan in China
}

\author{
Yu Lihong \\ School of Economics and Management \\ Shenyang Agricultural University \\ Shenyang, China \\ E-mail: jane_yu2008@163.com
}

\author{
Dai Lin \\ School of Economics and Management \\ Shenyang Agricultural University \\ Shenyang, China \\ E-mail: 834712952@qq.com
}

\begin{abstract}
To study the development situation of rural land management right mortgage loan in China, this paper, taking pilot Faku County, in Liaoning province as an example, summarized the main practices and achievements of rural land management right mortgage loan, and analyzed the problems in the practice. The paper draws the conclusion that the practice in Faku County plays an important role in easing the households' credit constraints, promoting the development of the agriculture and rural economic. Pilots about rural land management right mortgage loan are worth promoting. In order to promote the establishment of rural land mortgage loan system, the government should give support and guiding, and financial institutions should participate actively the business, and the perfect rural land circulation market also should be set.
\end{abstract}

Keywords-Rural land management right; Mortgage loan; Finance innovation; Practical experiences; Investigation and analysis

\section{INTRODUCTION}

In recent years, the government pays increasing attention to rural areas, takes a series of measures to promote the development of rural finance, and the initial success of these measures have gradually appeared, but the problem of financing is still the biggest bottleneck in the development of the rural economy. "Financing is difficult, and difficulty is in no collateral", and there are not effective property except for the land contractual management right can be used to mortgage for farmers, therefore, inevitably the development of farmers is restricted due to financial bottlenecks. In order to solve the problem of financing in rural areas, in October 2008, the Central Bank and China Banking Regulatory Commission select some counties from nine provinces, such as Shandong, Liaoning, as pilots to promote the innovation of rural financial products and services. As a pilot county, Faku County introduces the financial innovation called "land contractual management right mortgage loan". With the business development of the rural land contractual management right mortgage loan, financial services in rural areas are improved, and financing channels for farmers are broaden, bottleneck in loans for farmers is solved, and it also promotes the development of the agriculture and rural economic, and plays an important role in rationally allocating agricultural resources.

The arable land of the Faku County is about 200 million acres, a little more than 5.5 acres of land per capita, mostly in the plains. With the adjustment of agricultural structure and the improvement of productivity, the requirement of large-scale operation and industrial development is becoming increasingly strong. Combined with the advantage of the resources of the Faku County, it has developed six characteristic industries: marigold, chili, raspberry, grapes, peanuts and livestock. It also constructs many agricultural economic zones and various types of cooperatives. Several major characteristic industries have begun to take shape, and cooperatives also are booming, such as marigold industry and chili professional cooperatives in Changgangzi village. The development of special industries and cooperatives in the Faku County need financial support, but farmers and cooperatives do not have sufficient collateral, and have never been given a full and effective financial support, so that the rural finance has been in a "short board" status. The implement of rural land management right mortgage loan plays an important role on easing farmers' credit constraint.

\section{MAIN PRACTICES OF LAND MANAGEMENT Right MORTGAGE LOAN IN FAKU COUNTY}

Rural Credit Cooperatives and Postal Savings Banks in Faku County have carried out the rural land management right mortgage loan business, and 12 million yuan have been loaned to farmers involving 178 farmers and two cooperatives, and the area of mortgage land is up to 4988.45 acres.

\section{A. Introducing Policies and Establishing the Institution}

In 2009, the Faku County government issued "Guidance to rural land contractual management right mortgage loan in Faku County" and "Interim Measures for the management of rural land contractual management right mortgage loan in Faku County" by the files of No. 5 and No. 8 respectively. To make sure the rural land management right mortgage work carries out in an orderly manner, the county strengthens the circulation service of rural land contractual management right. In March 2009 the circulation center and assessment committees of rural land management right in Faku County were set up, subsequently 20 rural land management right circulation services offices of township and 309 rural land management right circulation service stations of village were established. These measures provide a good political and organizational environment to carry out the rural land management right mortgage loan in the county. 


\section{B. Grasping the Principles and Running Normatively}

In order to ensure the smoothly running of the innovative pilot, Faku County introduced the policy measures of rural land management right mortgage according to the principle of "three no" (Do not change the nature of collective ownership of land, do not change the land use, do not harm the interests of farmers), and this principle was also reflected in the actual operation of the pilot. Running the program strictly accordance with the relevant policies and standardizing the loan system and process make the rural land management right mortgage loan pilot run smoothly in a standardized environment, and provide a guarantee for the pilot work.

\section{Increasing Input and Compensating Risk}

There are two mainly reasons that implementation of rural land management right mortgage loan is difficult, on the one hand, the rate of rural land management right mortgage loan is higher than the rate of the general lending, on the other hand, there is a certain risk of the loan, and banks need consider the various factors, this makes it relatively difficult to develop for the business. In response to these realities, the relevant departments of the Faku County developed "Interim Measures of the use of interest subsidy funds and risk compensation about rural land contractual management right mortgage loan in Faku County". If the lending rate is higher than the rate of the rural credit of Rural Credit Cooperatives, the government will give farmers interest subsidies. Faku County has arranged 500 million yuan earmarked for risk compensation of rural land contractual management right mortgage loan.

\section{ACHIEVEMENTS OF LAND MANAGEMENT RIGHT MORTGAGE LOAN IN FAKU COUNTY}

\section{A. Easing the Households' Credit Constraints}

As financial enterprise, Faku Credit Cooperatives have to expand the credit scale and reduce the lending risk to gain profit. Due to the provision of mortgage, rural land management right mortgage loan eliminates concerns of directors and managers in Rural Credit Cooperatives. A number of staff of Rural Credit Cooperative have said that if there is no collateral or guarantee of cadres or capable person, Rural Credit Cooperatives will not easily lend to farmers .Even policy and higher authorities call for them, the Rural Credit Cooperatives and credit officers would rather less the business than to take a risk. Seeing from the psychology and behavior of credit officers and the Rural Credit Cooperatives, farmers lacking collateral are a fundamental problem in China's rural areas. The development of rural land management right mortgage loan improves the enthusiasm of banks granting loans.

\section{B. Farmers' Repayment on Time}

Farmers are restricted by effective rules, so they actively repay the loan on time, and the banks have no bad loans .Survey results show that, the repayment rate is $100 \%$ and there is no non-performing loans occurred. This phenomenon is mainly for two reasons. From an economic point of view, the farmers who use the rural land management right as mortgage, will lose their lands if they can not repay the loan, so they will actively repay the loan.
From a social point of view, Village is characterized as "acquaintance society", farmers get humiliated if others pay the loans and get their lands, so it forces the farmers to be honest. With the maturity of the loans, in order to obtain their lands, most of the farmers will do everything possible to repay the loans. Therefore, with constraints of economic and social, farmers repay on time.

\section{Achieving a win-win effect among financial institutions, borrowers and rural economy}

The mode of land management right mortgage loan has achieved a win-win effect among rural financial institutions, borrowers and the rural economy in Faku country. For financial institutions, as a financial product, land management right mortgage loan increases the variety of financial products in financial institutions and expands their own business. For borrowers, land management right mortgage loan promotes the increase in the income of farmers and the Cooperatives. After obtaining land mortgage loans, they will invest the money to buy seeds, fertilizer, feed and other agricultural production data, increasing the agricultural output and farmers' income. Besides the implementation of land management right mortgage loan also promotes the adjustment of agricultural industrial structure in Faku Country, such as pepper industry, marigold industry and raspberry industry have developed rapidly. Practice has proved that rural land management right mortgage loan has adapted to the need of rural land scale operation and met the development of the current agriculture industrialization, and it has high practical value and wide promotion space.

\section{ThE PROBLEMS IN THE RUNNING OF LAND} MANAGEMENT RIGHT MORTGAGE LOAN IN FAKU COUNTY

\section{A. Legal Restrictions}

In the current, the most important issue is the legal limit problems in the rural land management right mortgage pilot. Although the land management right mortgage loan has carried out in the pilot, large-scale land mortgages remain restricted. "Guarantee Law of the People's Republic of China", article 37 stipulates that: "Collective ownership of land use rights in arable land, homestead, private plots and segment, may not be mortgaged." "The Interpretation of the Applicable Law on the Trial of Cases Involving the Rural Land Contract Disputes "issued by the Supreme People's Court, confines that if family contractors make their land contractual management rights to mortgage or cover the debt, it should be found to be invalid." Subject to the existing laws and regulations, relevant financial institutions face a lot of risks and uncertainty of the realization of mortgage and disposal of collateral, and thus affecting the enthusiasm of doing this business. Now the main problem is that there are loan demand for the farmers and the willingness to promote the business for government, but the obstacles in the operation for financial institutions.

\section{B. Difficulty in Disposaling the Collateral}

When put rural land management right as collateral, it is difficult to disposal the collateral. According to the 
survey, at present, the rural financial institutions do not want to run the mortgage business, and the main reason for this situation is difficult to disposal the land management right. The negotiable land management right can not change the nature of ownership and the use, at the same time, due to the slow development of the market for transferring, lack of the authority transfer intermediary, and the poor transfer information, once the farmer defaults, it difficult for banks to dispose of the mortgaged land management right, and land management right is difficult to liquidate. The poor cash ability of rural land management right, greatly restricts the enthusiasm of financial institutions to carry out the rural land management right mortgage. In the investigation, some people think that the practical constraints of rural land mortgage business are "difficult to disposal of collateral", and the number of people who support this idea account for $61.67 \%$.

\section{Lacking of Professional Assessment Agencies}

In practice of innovation, due to different evaluation criteria on the collateral value of the land management right, the lack of scientific evaluation indicators and evaluation criteria, it will be a different risk when the value of the land is recognized too high or too low. If the land valuation is lower, exchange value and marketability of land management right can not through the market to get a fair performance, finally, it transfers the risk to farmers. While farmers make use of land management right to obtain loans, also bear a higher risk, obviously, this situation can not effectively protect the interests of farmers, and can not be conducive to the development of rural finance. If the value of the land identified is too high, due to agricultural production facing a complex and volatile risk, the risk of financial institutions to recover loans further increases, easy to form the non-performing loans. In the investigation, $47.09 \%$ of respondents believe that the practical constraint of rural land mortgage is collateral assessment.

\section{The Weak Will of Financial Institutions Carryingout Land Mortgage Loan Business}

The survey shows that $60.29 \%$ of respondents believe that there are a lot of potential in rural land mortgages, but only $45.66 \%$ of the respondents expressed their will to carry out the rural land mortgage. Part of the loan officers makes it clear that only land assessment supporting measures are well improved, they are willing to carry out rural land mortgage. From the above survey, we can know that $82.35 \%$ of credit officers think that it is some necessary or necessary to carry out the business of rural land mortgage, but when asked about their own will to carry out this business, only $45.66 \%$ of the respondents expressed their will to carry out, and part of them are attached with conditions .So the will of financial institutions is not strong to carry out the business.

\section{E. Contradiction between the Farmers' Land Area and Loan Expectation}

First, there are 5.5 acres of land per capita in Faku county, so there is a certain contradiction between less land assessment value and higher loan expectation for farmers; Second, land management right mortgage loan is only in cooperatives and large plantations, and the number of beneficiary population is little, so the development of the rural economy will be restricted; Third, further research about farmers how to use the rent land to achieve a mortgage should be taken.

\section{POLICY RECOMMENDATIONS IN PROMOTION OF}

\section{RURAL LAND MANAGEMENT RightS MORTGAGE LOAN}

\section{A. Polit in Land management right mortgage loan is worth promoting}

Land management right mortgage loan plays an important role to solve the farmers' lack of collateral issues, to ease the problems of difficulty in getting loan for farmers and the credit crunch problems with financial institutions, to promote the development of rural finance and rural economy, and land management right mortgage loan will not cause farmers lose their lands. For this reason, it is recommended that the government should select more qualified rural areas to expand the scope and level of the pilot, then sum up experience, improve way of mortgage, and gradually promote the mode of rural land management right mortgage loan.

\section{B. Adhering to the Principle of"Three Must" in the Process of Implementation}

First, we must adhere to a certain percentage of collateral to ensure the rights of the farmers, and also reducing the risk of financial institutions. Rural social security system is not yet fully established, and the land is the foundation for the farmers, if land management rights are fully collateralized, once the farmers can not repay the debt, they will be landless, then threatening the survival of farmers and the stability of the rural social. The second is to adhere to a certain range of collateral. When the borrower can not repay the loan in time, land management rights is also confined to the circulation of town or administrative village, and should not change the use of the land after circulation. The third is to adhere to a certain term of collateral. When the borrower can not repay the loan in time, the circulation period of land management rights should be not longer than the period of the contract with remaining maturity, then to protect the survival rights of farmers.

\section{Bringing up Relevant Policies according to Local Conditions}

Although conditions are not yet ripe for full liberalization of the rural land management right mortgage loan from a nationwide perspective, in the areas that the rural labor force has a large number of stable transfer and social security measures are relatively completed should explore and try to run the rural land mortgage business. Therefore, it is recommended to modify and improve the relevant provisions of the "Rural Land Contract Law "and" Property Law ", and cancel the restrictions of rural land management right mortgage, or clearly define land management right to mortgage, so that it can provide relevant legal basis for rural land mortgage financing.

\section{Accelerating the Construction of Rural Land Assessment Market}

Lacking of generally accepted property valuation standards and difficulty to estimate the value of property 
rights, make it difficult to determine the line of credit, and largely weaken the mortgage. In order to play the role of property rights mortgage and avoid undervaluation of the villagers' property rights, it is recommended to formulate the "assessment and management approach of rural land management right", and introduce intermediaries to assess the collateral value of rural land management right, reasonably to determine the value of rural land.

The relevant government departments should establish independent land transfer assessment centers that are independent management and self-financing centers, train professional qualification assessment personnel, standardize the value assessment of the land management right, and create favorable conditions for the banking institutions in rural land management right mortgage loan.

\section{E. Establishing and Improving the Rural Land Transfer Market}

According to the situation of the national pilots, the areas where land contract management right mortgage loans are going well are the areas where the local rural land transfer is more active. The level of land circulation and management can be the premise and basis of the development of rural land mortgage loan successfully. At the same time, they are a virtuous circle and they can promote each other. Therefore, it is suggested to set up specialized intermediaries as soon as possible, responsible for the transfer and transaction of rural land, through standardized operation and management, to gradually nurture and expand the demand and scale of rural land transfer, so that providing a good foundation for the rural financial product innovation.

\section{F. Improving gradually the Agricultural Safeguard Mechanism}

To reduce the credit risk of the rural land management right mortgage loan, it should speed up the establishment of the agricultural credit guarantee institutions and the development of agricultural insurance. It should encourage and support the insurance companies offering agricultural insurance business, and appropriate compensation for the loss of agricultural insurance. Rural financial institutions should actively explore a variety of guarantees, to further improve the ability to prevent credit risks.

\section{ACKNOWLEDGMENT}

Thanks to the support of the funds. The funds are Youth Project of the National Natural Science Foundation, "the follow-up study of rural land management rights mortgage: supply and demand, the effect and mechanism analysis" (71203147), Humanities and Social Science Fund of the Ministry of Education, Youth Project "rural land contract management rights mortgages operational mechanism and performance evaluation "( 11YJC790249), the Science and Technology Planning Project of Science and Technology Bureau of Shenyang City" study on the rural land contracted management rights mortgage loan in rural land circulation in Shenyang city" (F13-315-5-03)," study on farmer professional cooperatives financing difficulties and financing mode selection in Shenyang city" (F13-315-5-02), and Social Science Planning Fund of Liaoning Province (L12BGL013).

\section{REFERENCES}

[1] Wright, Ivan. Farm Mortgage Financing. New York: McGraw-Hill Book Company, Inc, 1971

[2] Carter, M.R., and P. Olinto. Getting institutions " Right" for Whom? Credit Constraints and the Impact of Property Rights on the Quantity and Composition of Investment, American Journal of Agricultural Eco- nomics, Vol. 85, No.1, pp.173 186, 2003.

[3] Helmut Bester. Screening vs. Rationing in Credit Markets with Imperfect Information, The American E- conomic Review, vol.75, pp.850 855, 1985.

[4] Field, E, and M.Torero. Do Property Titles Increase Credit Access Among the Urban Poor? Evidence from a Nationwide Titling Program, Working Paper, Department of Economics, Harvard University, pp.24-25, 2006

[5] Lin Lefen, Zhao Qian, Promote the innovation of rural land financial system - based on the mortgage loans of rural land contract management rights, Xuehai,2009.5,pp68-72

[6] Chen Xiaofu, Li Mengjun. Reflections on the mortgage experimental work of rural land contract management rights, Wuhan Financial 2010.5,pp63-64

[7] Yan Xingchen, Du Nana. Study on the new model of the rural land contract management rights mortgages. The Western Accounting, 2011.4,pp49-51

[8] Qiu Jiqin, Qiu Daochi, Wang Ping. Challenges and policies of rural land mortgage - a case study of kaixian in Chongqing. Rural Economic 2012.2,pp34-37

[9] Lin Lefen Zhao Qian, Promote the Financial System Innovation of Rural Land - Mortgage Loans Based on Rural Land Contract Management Rights, Xuehai,2009.5,pp68-72

[10] Zhang Qingjun, Thinking of the Mode of Rural Financial Innovation in Land Mortgages, Rural Economy,2010.11,pp64-66

[11] Zhai Xiangwei, Thinking of the Promotion of Rural Land Contract Management Rights Mortgage Business, Financial Theory and Practice,2010.8,pp54-55 